\title{
Pantoea agglomerans as a New Etiological Agent of a Bacterial Necrotic Disease of Mango Trees
}

\author{
José A. Gutiérrez-Barranquero, Francisco M. Cazorla, Juan Antonio Torés, and Antonio de Vicente†
}

First, second, and fourth authors: Instituto de Hortofruticultura Subtropical y Mediterránea (IHSM-UMA-CSIC), Departamento de Microbiología, Facultad de Ciencias, Universidad de Málaga, 29071 Málaga, Spain; and third author: IHSM-UMA-CSIC, Estación Experimental "La Mayora", 29750 Algarrobo-Costa (Málaga), Spain.

Accepted for publication 7 August 2018.

\begin{abstract}
Bacterial apical necrosis of mango trees, a disease elicited by Pseudomonas syringae pv. syringae, is a primary limiting factor of mango crop production in the Mediterranean region. In this study, a collection of bacterial isolates associated with necrotic symptoms in mango trees similar to those produced by bacterial apical necrosis disease were isolated over five consecutive years in orchards from the Canary Islands. The bacterial isolates were characterized and identified as Pantoea agglomerans. Pathogenicity tests conducted on onion bulbs and mango plants confirmed that $P$. agglomerans strains isolated from mango trees are a new etiological agent of a bacterial necrotic disease in the Canary Islands. Pathogenicity plasmids of the pPATH family have been previously reported in $P$. agglomerans. The majority of putatively pathogenic $(n=23)$ and pathogenic $(n=4)$ P. agglomerans strains isolated from mango trees harbored four plasmids, one of which was close in size to the

135-kb pPATH pathogenicity plasmid. The analysis of the presence of two major genes in pPATH plasmids (repA and $h r p J$ ) was undertaken in $P$. agglomerans strains isolated from mango trees. The hrpJ gene was detected in the $140-\mathrm{kb}$ plasmid of pathogenic P. agglomerans strains isolated from mango trees but it showed differences in nucleotide sequences compared with other pathogenic strains. In contrast, the repA gene was not detected in any of the putatively pathogenic and pathogenic $P$. agglomerans strains isolated from mango trees. Finally, genetic characterization and phylogenetic analysis using the $h r p J$ gene and the housekeeping genes gyrB and $r p o B$ showed that almost all $P$. agglomerans strains that were putatively pathogenic and pathogenic on mango trees clustered together, forming a differentiated phylogroup with respect to the other pathogenic P. agglomerans strains described from other hosts.
\end{abstract}

The mango tree (Mangifera indica L.) is widely distributed in many tropical and subtropical areas and represents one of the most important subtropical fruit crops worldwide (Galán Saúco 2015). Mango crops are affected by several diseases elicited by bacterial and fungal pathogens. The most severe bacterial diseases are bacterial black spot, caused by Xanthomonas citri pv. mangiferaindicae (Gagnevin and Pruvost 2001), and bacterial apical necrosis (BAN), caused by Pseudomonas syringae pv. syringae (Cazorla et al. 1998), which is the most important limiting factor for the production of this crop in Southern Europe (Cazorla et al. 1998, 2006). BAN has also been described to be present in other countries in the Mediterranean region, such as Israel (Pinkas et al. 1996) Italy (Aiello et al. 2015), and, more recently, Greece (Trantas et al. 2017), but has also been detected in other parts of the world with tropical and subtropical climates such as the northwest region of Australia (Golzar and Cother 2008) and Pakistan (Naqvi et al. 2016). Unusually, only a few reports have described the role of some Enterobacteriaceae species as pathogens of mango crops, such as Erwinia spp. (Guevara et al. 1980; McMillan and Wang 1992) and Pantoea agglomerans (Lee and Tzeng 2006).

${ }^{\dagger}$ Corresponding author: Antonio de Vicente; E-mail: adevicente@uma.es

Funding: This work has been supported by grants from CICE-Junta de Andalucía, Proyecto de Excelencia cofinanced by FEDER (EU) (P07-AGR-02471 and P12AGR-1473)

This work is dedicated to the memory of Juan A. Torés (1952-2018), a pioneer in the discovery of BAN disease, who passed away during the publication process of this work.

*The $e$-Xtra logo stands for "electronic extra" and indicates that three supplementary tables are published online.

(C) 2019 The American Phytopathological Society
P. agglomerans is a bacterium that is widely distributed in agricultural and natural environments (Delétoile et al. 2009). This species has been observed to be associated with many different plants, frequently as epiphytic and endophytic bacteria, and it has also been widely used as a potential biological control agent against fungal and bacterial plant pathogens (Walterson and Starvinides 2015). However, this bacterium can also cause secondary infections in humans in soft tissues, bones, and joints, which can develop into bacteremia (Büyükcam et al. 2018; Cheng et al. 2013; Cruz et al. 2007). Interestingly, P. agglomerans has been naturally transformed into a gall-forming plant pathogen by the acquisition of pathogenicity plasmids belonging to the pPATH family (Manulis and Barash 2003). The two best-studied model of $P$. agglomerans pathogenic strains are P. agglomerans pv. gypsophilae 824-1 and P. agglomerans pv. betae 4188, which differ in host range (Burr et al. 1991; Cooksey 1986) and in gall formation in specific plant hosts (Burr et al. 1991; Manulis and Barash 2003). Both strains harbor a similarly sized pPATH plasmid (approximately $135 \mathrm{~kb}$ ), although the best studied is the plasmid from strain 824-1. This pathogenicity plasmid carries an important $75-\mathrm{kb}$ pathogenicity island (PAI) that encodes hrp/hrc type III secretion system genes (T3SS), T3SS protein effector-encoding genes, and genes involved in the production of phytohormones (Barash and Manulis-Sasson 2007, 2009). In the last two decades, several studies have reported that the transformation of $P$. agglomerans into pathogenic strains is not restricted only to the pathovars gypsophilae and betae but also has been described to incite the production of tumors (DeYoung et al. 1998; Opgenorth et al. 1994) and, more frequently, necrotic rot and wilt symptoms in many other plant hosts (González et al. 2015; Lee et al. 2010; Lu et al. 2015; Tho et al. 2015; Yang et al. 2011).

In this study, necrotic symptoms affecting different mango tissues were observed in mango trees in Canary Islands orchards (Spain) over five different years. Bacterial isolation identified bacterial strains 
other than Pseudomonas syringae pv. syringae, the original etiological agent of BAN of mango trees. Thus, the main goal this work was to characterize and identify these bacterial isolates associated with necrotic symptoms of mango trees and to demonstrate their pathogenicity on mango trees. Following different biochemical and physiological tests, most of these bacterial isolates were identified as Pantoea agglomerans, and the pathogenicity of five selected strains was confirmed in mango adult plants. Moreover, plasmid characterization revealed the presence of plasmids other than those belonging to the pPATH pathogenicity family in pathogenic P. agglomerans strains isolated from mango trees. Genetic and phylogenetic analyses revealed a strong clustering of $P$. agglomerans strains isolated from mango trees that may represent a differentiated phylogroup with respect to other pathogenic P. agglomerans strains previously described from other hosts.

\section{MATERIALS AND METHODS}

Isolation, characterization, and identification of bacterial isolates. Commercial mango orchards in the Canary Islands, Spain, primarily from Tenerife and La Palma, were surveyed in this study for the presence of necrotic symptoms. To isolate the causal agent of the necrotic symptoms, small pieces of affected leaves, buds, stems, flower panicles, and immature fruit were cut from the edges of necrotic lesions, placed in sterile plastic bags, and transported to the laboratory for processing. The samples were processed by two different methods. (i) Some portions were surface disinfected by immersion in a sterile aqueous solution of $0.1 \%$ (wt/vol) $\mathrm{HgCl}_{2}$ for $1 \mathrm{~min}$, rinsed twice in sterile distilled water for $1 \mathrm{~min}$ each, and plated onto agar-solidified King's medium B (KB) (King et al. 1954) supplemented with cycloheximide $(100 \mu \mathrm{g} / \mathrm{ml})$. (ii) The remaining samples were homogenized in a lab blender for $3 \mathrm{~min}$ with sterile phosphate buffer $(0.1 \mathrm{M}, \mathrm{pH} 7.2)$ at $10 \mathrm{ml} / \mathrm{g}$ of fresh plant material, after which $100 \mu \mathrm{l}$ was spread onto KB plates supplemented with cycloheximide. All $\mathrm{KB}$ plates were incubated at $25^{\circ} \mathrm{C}$ for 2 days.

The bacterial isolates were identified according to biochemical and physiological tests described previously (Bradbury 1986; Lelliott and Stead 1987), including Gram staining; glucose metabolism; growth on yeast extract-dextrose-calcium carbonate agar; production of fluorescent pigments; and levan production, oxidase reaction, potato soft rot, arginine dihydrolase, and tobacco hypersensitivity response (HR) tests, excluding the potato soft rot analysis. HR elicitation in resistance and nonhost plants such as tobacco is generally dependent on T3SS in Gram-negative bacterial pathogens (Lindgren 1997), as has also been reported in P. agglomerans (Nizan et al. 1997).
Subsequently, indole production and nitrate reduction assays were performed. All of the results obtained from these tests are summarized in Table 1. All inoculated media were incubated at $25^{\circ} \mathrm{C}$ for 2 to 3 days. Duplicate tubes or plates were assayed for each test, and tests were repeated at least twice. All of the bacterial isolates identified in this study are summarized in Supplementary Table S1. Several bacterial strains of different species were used as controls (Supplementary Table S2) for the different biochemical and physiological tests.

Pathogenicity tests on onion bulbs and mango plants. To determine whether the isolated $P$. agglomerans was the causal agent of necrotic symptoms observed in mango trees in Canary Islands, two different pathogenicity tests were performed to fulfill Koch's postulates.

First, a pathogenicity test in onion bulbs following the procedure of Kim et al. (2002) and Jacobs et al. (2008) with minor modifications was carried out. Three different commercial onion bulbs were used per bacterial strain inoculated, and this experiment was repeated twice. Onion bulbs were initially devoid of their outer coverings, and their surfaces were washed with sterile water before and after being disinfected with ethanol $70 \%$. Next, the bacterial strains selected for this experiment were inoculated by injection using sterile syringes. Bacterial suspensions $\left(20 \mu \mathrm{l}\right.$ of $\left.3 \times 10^{7} \mathrm{CFU} / \mathrm{ml}\right)$ in phosphate buffer were used for each onion bulb. Onion bulbs were maintained at $25^{\circ} \mathrm{C}$ in darkness for 28 days in closed boxes lined with damp blotting paper. The production of symptoms was estimated after this time. A positive score was recorded when bulb rot symptoms were observed in the center of the onion bulbs, and a negative score was recorded when no bulb rot symptoms appeared. Ten representative $P$. agglomerans strains isolated from mango trees were selected by year of isolation (two bacterial strains per year: UMAF3066, UMAF3067, UMAF3075, UMAF3078, UMAF3084, UMAF3086, UMAF3090, UMAF3093, UMAF3098, and UMAF3101), including one that was negative for HR response (UMAF3090) and one that was isolated from another location, La Palma (UMAF3098), and were assayed. Similarly, two strains of P. agglomerans (CECT850 and CFBP4740), P. stewartii subsp. indologenes CFBP3614, and phosphate buffer were used as controls. Reisolation and identification of the etiological agent through biochemical and physiological tests was carried out at the end of the experiment.

Second, to test the pathogenicity of $P$. agglomerans, Koch's postulates were fulfilled using 302 -year-old mango plants growing in pots. Buds of mango plants were inoculated with $20 \mu \mathrm{l}$ of a bacterial suspension $\left(3 \times 10^{7} \mathrm{CFU} / \mathrm{ml}\right)$ in phosphate buffer, with the inoculum forced into buds with a sterile microsyringe, as previously

TABLE 1. Physiological and biochemical tests performed in this study to identify the bacterial isolates $(n=44)$ from necrotic lesions in different tissues in mango trees in Canary Islands, Spain

\begin{tabular}{|c|c|c|c|c|}
\hline \multirow[b]{2}{*}{ Test } & \multicolumn{4}{|c|}{ Physiological and biochemical profiles of bacterial isolates ${ }^{\mathrm{a}}$} \\
\hline & Bt1 & $\mathrm{Bt} 2$ & Bt3 & $\mathrm{Bt} 4$ \\
\hline Morphology & Coccobacillus & Coccobacillus & Coccobacillus & Coccobacillus \\
\hline Gram stain & - & - & - & - \\
\hline Fluorescence & - & - & - & + \\
\hline Glucose metabolism ${ }^{\mathrm{b}}$ & $\mathrm{F}$ & $\mathrm{F}$ & $\mathrm{F}$ & $\mathrm{O}$ \\
\hline $\mathrm{YDC}^{\mathrm{c}}$ & Y & Y & $\mathrm{Y}$ & $\mathrm{W}$ \\
\hline Levan production & + & + & + & + \\
\hline Oxidase & - & - & - & - \\
\hline Arginine dihydrolase & - & - & - & - \\
\hline Tobacco hypersensitivity & + & - & - & + \\
\hline Identification & Pantoea spp. & Pantoea spp. & Pantoea spp. & Pseudomonas syringae \\
\hline Indole production & - & - & + & - \\
\hline Nitrate reduction & + & + & - & - \\
\hline Number of isolates & 29 & 4 & 5 & 6 \\
\hline Identification & Pantoea agglomerans & P. agglomerans & P. ananatis & Pseudomonas syringae \\
\hline
\end{tabular}

${ }^{\mathrm{a}} \mathrm{Bt}=$ bacterial type.

${ }^{\mathrm{b}}$ Metabolism of glucose: $\mathrm{O}=$ oxidative and $\mathrm{F}=$ fermentative.

${ }^{c}$ Growth on yeast extract-dextrose-calcium carbonate agar (YDC): W= white colonies and Y= yellow mucoid colonies. 
described (Cazorla et al. 1998). In all, 5 representative $P$. agglomerans strains isolated from mango trees selected by year of isolation from the previous 10 bacterial strains used in onion bulbs (UMAF3067, UMAF3075, UMAF3084, UMAF3093, and UMAF3098) were used for this experiment. In addition, two Pseudomonas syringae pv. syringae strains (UMAF0048 and UMAF0049), both producers of BAN symptoms in mango trees, were used as positive controls, and Pantoea agglomerans CFBP4740 and phosphate buffer were used as negative controls. Each assayed strain was injected into seven buds of different mango plants in a random manner. After bacterial inoculations, the trees were maintained under field conditions from February to June 2010 at "La Mayora" Experimental Station (Algarrobo, Spain). The disease incidence was measured by the percentage of necrotic symptoms in buds compared with the total inoculated buds $(n=35)$. Reisolation from necrotic symptoms and identification through biochemical and physiological tests of bacterial isolates was carried out at the end of the experiment.

Plasmid profile characterization. Plasmid DNA from the $P$. agglomerans strains isolated from mango trees was isolated by extracting total uncut plasmid DNA from Lysogeny broth cultures grown overnight (Moulton et al. 1993) and separated by electrophoresis on $0.8 \%$ agarose gels. The plasmid sizes were estimated by comparison with those isolated from P. agglomerans pv. gypsophilae 824-1, which harbors two plasmids, a pathogenicity pPATH plasmid of approximately $135 \mathrm{~kb}$, and another plasmid of approximately $60 \mathrm{~kb}$ (Manulis et al. 1991).

Polymerase chain reaction detection and sequencing of the plasmid-encoded $h r p J$ and repA genes. The repA gene is required for the replication of pPATH plasmids (Weinthal et al. 2007). To detect the presence of this gene in P. agglomerans strains
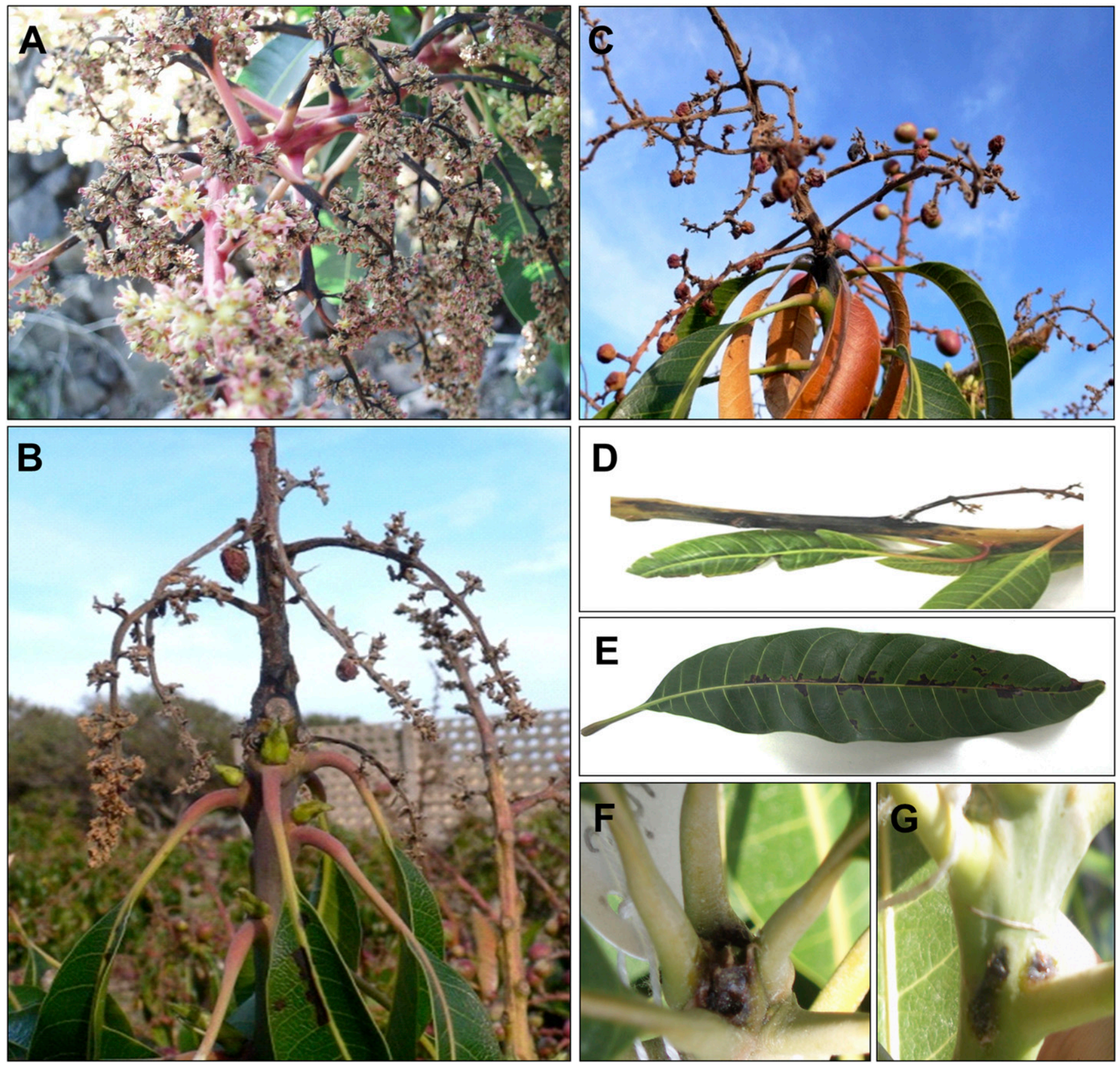

D
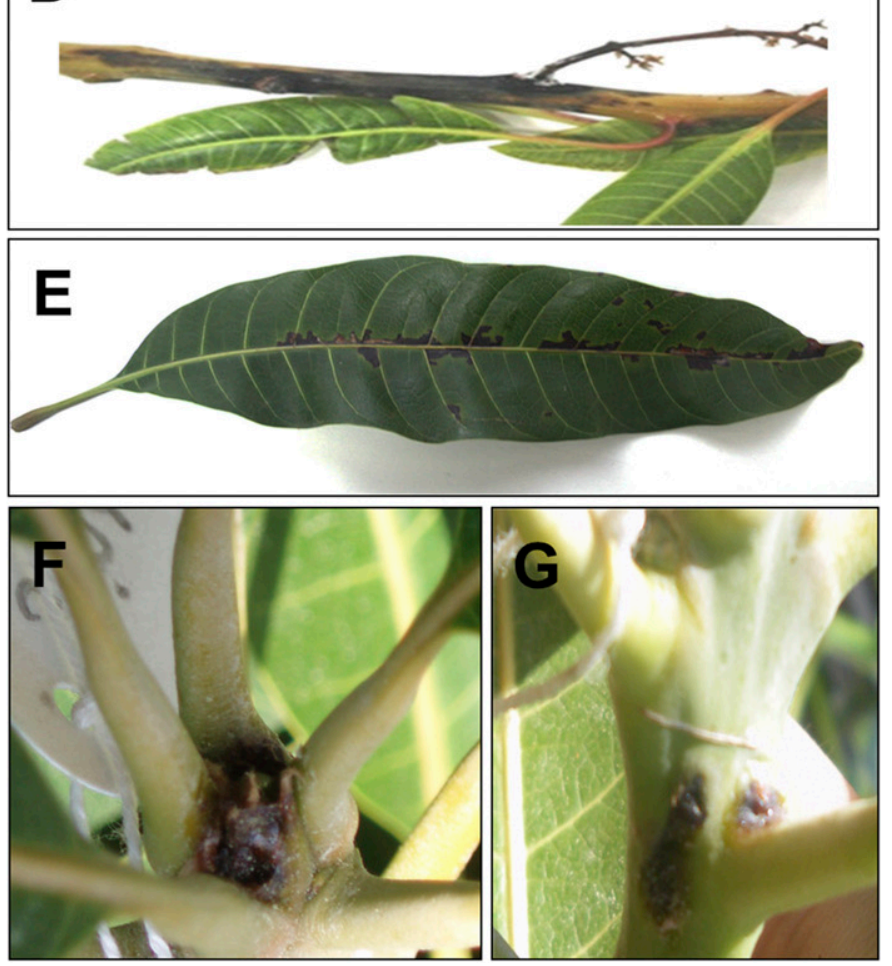

Fig. 1. Necrotic symptoms on mango trees in Canary Islands. A, Initial necrosis of flower panicles; B, advanced necrosis of flower panicles; C, necrosis of immature fruit; $\mathbf{D}$, necrotic symptoms in branches; $\mathbf{E}$, necrotic spots in leaves; $\mathbf{F}$, detail of necrotic symptoms in mango bud, and $\mathbf{G}$, necrotic symptoms in stems, both experimentally inoculated with representative strains of Pantoea agglomerans. 
isolated from mango trees, specific primers designed in this study using the repA sequences of strains 824-1 and 4188 (GenBank accession numbers EF173387.1 and EF173388.1, respectively) were used for polymerase chain reaction (PCR) amplification and sequencing (repAFsp: 5'-GCTGACTGAAGCTGCTTATC-3' and repARsp: 5'-AGACTCAGGCAGCATGAATC-3'), which generate a predicted amplicon of $499 \mathrm{bp}$. Nucleotide sequences were determined at Macrogen (Seoul, Korea).

The hrpJ gene is a key gene of the T3SS. A PCR experiment using specific primers designed previously for the $h r p J$ gene sequence present in pPATH plasmids (GenBank accession number: X99768.2 and primers hrpj5n1: 5'-CGCCAGGATGAAAATTGCTC- $3^{\prime}$ and hrpj3n1335: 5'-CGCAGCCGATTCAACGCC-3') was carried out (Weinthal et al. 2007) to assess its presence in P. agglomerans strains isolated from mango trees. Five representative bacterial strains (UMAF3067, UMAF3075, UMAF3084, UMAF3093, and UMAF3098) as well as strains 4188 and 824-1 were used to determine the partial nucleotide sequence of the $h r p J$ gene. DNA amplicons were purified from an agarose gel, cloned into the pGEM-T vector (Promega Biotech, Ibérica, Spain), and transformed into chemically competent Escherichia coli DH5 $\alpha$ cells. Purified plasmids were used to sequence the insert DNA region. Nucleotide sequences were determined at Macrogen. Afterward, the specific primers designed in this study (hrpJPaF: 5'GACCTTCGCGGAACAGGTTG-3' and hrpJPaR: 5'-CGGCA GATGGTAGACCAG- $3^{\prime}$ ) based on the $h r p J$ sequences, obtained as described above, were used to amplify and sequence a partial region of this gene $(803 \mathrm{bp})$ for the $P$. agglomerans strains isolated in this study.
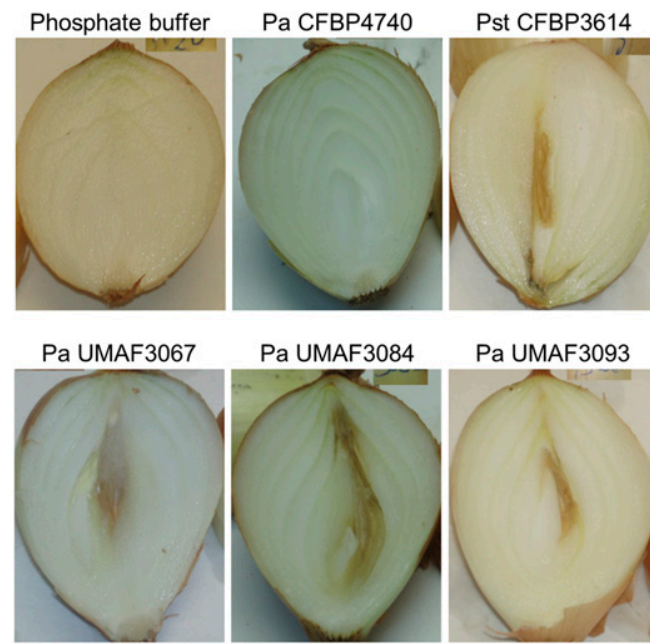

Fig. 2. Pathogenicity test in onion bulbs using selected Pantoea agglomerans strains. Ten strains of $P$. agglomerans isolated from mango were tested (UMAF3066, UMAF3067, UMAF3075, UMAF3078, UMAF3084, UMAF3086, UMAF3090, UMAF3093, UMAF3098, and UMAF3101). Just five representative strains were included in this figure. Positive control $=P$. stewartii subsp. indologenes (Pst) CFBP3614. Negative controls $=P$. agglomerans $(\mathrm{Pa})$ CFBP4740 and phosphate buffer.
PCR amplification conditions for the different amplifications described previously are summarized in Supplementary Table S3.

Southern blot experiments. The genomic location of the repA and $h r p J$ genes was assessed by Southern blot using plasmid DNA extractions that were separated by electrophoresis in $0.8 \%$ agarose gels. DNA probes were obtained by PCR amplification using the specific primers designed in this study for both genes (repAFsprepARsp and hrpJPaF-hrpJPaR). The DNA probes obtained from the purified PCR amplicons were labeled with digoxigenin (DIG) using a DIG-High Prime labeling kit (Roche, Basel, Switzerland) following the manufacturer's instructions. Strain 824-1 was included as positive control. Plasmid DNA extraction gels, which included strain 824-1 as positive control, were transferred to nylon membranes and crosslinked in a UV chamber. For membrane hybridization, a DIG Easy Hyb kit was used (Roche), and immunological detection was performed with an anti-DIG antibody conjugated to alkaline phosphatase. The DIG-labeled nucleic acids were detected by chemiluminescence using a Molecular Imager ChemiDoc system (Bio-Rad, UK). Prehybridization and hybridization at high stringency $\left(55^{\circ} \mathrm{C}\right)$ were performed for both the $h r p J$ and repA genes and at low stringency $\left(45^{\circ} \mathrm{C}\right)$ only for the $h r p J$ gene.

Genetic analysis. To perform a DNA fingerprinting of $P$. agglomerans strains isolated from mango trees, a repetitive element sequence-based PCR (rep-PCR) method was selected, using specifically BOXA1R primer (5'-CTACGGCAAGGC GACGCTGACG-3'). PCR amplifications were performed with a C1000 Thermal Cycler (Bio-Rad). The total volume of each PCR $(25 \mu \mathrm{l})$ was loaded onto a $1.2 \%$ agarose gel and run in $1 \times$ Trisacetate EDTA buffer (40 mM Tris-acetate and $1 \mathrm{mM}$ EDTA) at $80 \mathrm{~V} / \mathrm{cm}$ for $1.5 \mathrm{~h}$. Polymorphic band patterns were individually identified by their specific electrophoretic migration rates. Once bands were identified, binary matrices $(0 / 1)$ were constructed to compare those patterns. The Jaccard's similarity coefficient was generated using InfoQuest FP software (Bio-Rad), and a cluster analysis, along with the corresponding dendrogram, was generated by the unweighted pair-group method with average linkages. Gel normalization and background subtraction were performed as previously described (Rademaker et al. 2004).

Phylogenetic analysis. Partial sequences of the $h r p J$ gene and the housekeeping genes $g y r B$ and $r p o B$ were used to analyze the phylogenetic distribution of the $P$. agglomerans strains isolated from mango trees in comparison with some other Pantoea spp. strains. Nucleotide sequences were determined at Macrogen directly from purified PCR products amplified with the primer sets gyrB3i (5'-AACGCWATCGACGAAGC-3') and gyrB4i $\left(5^{\prime}\right.$-TGGAAVCCRTCRTTCCAC-3') for $g y r B$, and Vic $3\left(5^{\prime}-\right.$ GGCGAAATGGCWGAGAACCA-3') and Vic2 (5'-GAGTCTTC GAAGTTGTAACC-3') for $r p o B$ (Delétoile et al. 2009). The partial sequences of $g y r B(511 \mathrm{bp})$ and $r p o B(801 \mathrm{bp})$ were concatenated for each strain and treated as a single sequence for multiple alignments using Clustal Omega. Phylogenetic trees were generated using MEGA 6 (Tamura et al. 2013) with neighbor joining, Jukes-Cantor model, minimum evolution, and the option of complete deletion to eliminate positions containing gaps. Confidence levels of the branching points were determined using 1,000 bootstrap replicates. Strains 824-1, 4188, and other P. agglomerans control strains used

TABLE 2. Pathogenicity test in 2-year-old mango plants using selected Pantoea agglomerans strains isolated from mango

\begin{tabular}{|c|c|c|c|c|c|c|}
\hline \multirow[b]{2}{*}{ Bacterial isolates } & \multicolumn{6}{|c|}{ Disease incidence $(\%)$} \\
\hline & 28 days & 42 days & 56 days & 70 days & 84 days & 98 days \\
\hline Pseudomonas syringae pv. syringae $(n=2)^{\mathrm{a}}$ & 42.8 & 64.2 & 92.8 & 92.8 & 92.8 & 92.8 \\
\hline Pantoea agglomerans $(n=5)^{\mathrm{b}}$ & 0 & 0 & 17.1 & 42.8 & 80 & 100 \\
\hline P. agglomerans $\mathrm{CFBP} 4740^{\mathrm{c}}$ & 0 & 0 & 0 & 0 & 0 & 0 \\
\hline Phosphate buffer & 0 & 0 & 0 & 0 & 0 & 0 \\
\hline
\end{tabular}

${ }^{a}$ Bacterial strains inoculated: UMAF0048 and UMAF0049.

b Strains isolated from mango. Bacterial strains inoculated: UMAF3067, UMAF3075, UMAF3084, UMAF3093, and UMAF3098.

${ }^{c}$ CFBP4740 = nonpathogenic control strain. 
in this study (CFBP4740 and CECT850) were included, as well as P. stewartii subsp. indologenes CFBP3614.

Nucleotide accession numbers. The nucleotide sequences determined in this study are deposited at the National Center for Biotechnology Information under the following accession numbers: gyrB sequences (MH479140 to MH479183, MH643873, MH643874, and NC_017554.1), rpoB sequences (MH479184 to MH479227, MH643875, MH643876, and NC_017554.1), hrpJ sequences (MH479228 to MH479258), and repA sequences (MH479259 to MH479260).

\section{RESULTS}

Description of symptomatology. From different samplings carried out in the Canary Islands between February and March 2005 to 2009 , the presence of necrotic symptoms was not primarily associated with Pseudomonas syringae pv. syringae isolation. The symptomatology observed in mango trees in the Canary Islands, Spain, was similar to that symptomatology produced by BAN disease described in southern Spain elicited by $P$. syringae pv. syringae. The presence of random necrotic spots throughout the surface of the flower panicles (Fig. 1A) and a slight increase in the presence of necrosis of immature fruit in comparison with BAN symptoms (Fig. 1B and C) was observed. Necrosis on branches and random necrotic spots in leaves were also reported (Fig. 1D and E).

Bacterial isolation, characterization, and identification. Samples from different symptomatic mango tissues (leaf, stem, flower panicle, and immature fruit) were collected and analyzed and bacterial isolates were recovered. Bacterial isolation from diseased mango tissues yielded almost pure cultures of yellow colonies that were not fluorescent on KB under UV light. These yellow bacterial isolates $(n=38)$ showed similar biochemical and physiological features that are typical of species belonging to the genus Pantoea (Table 1). The indole production and nitrate reduction tests were used to discriminate among the species of the Pantoea isolates, identifying 33 as Pantoea agglomerans. The remaining five yellow isolates were identified as $P$. ananatis (Bt3; UMAF3070 to UMAF3074). With the exception of four strains isolated from mango trees (Bt2; UMAF3090, UMAF3094, UMAF3097, and UMAF3102), the five $P$. ananatis strains and the control strains 824-1 and 4188, the rest of the $P$. agglomerans strains produced a positive HR response at $24 \mathrm{~h}$ postinoculation in tobacco leaves (Bt1; $n=29)$. The HR elicitation suggests the pathogenic potential of these bacterial strains. Furthermore, six fluorescent strains on $\mathrm{KB}$ under UV light were also isolated (Bt4), characterized and identified as Pseudomonas syringae.

Pathogenicity tests revealed the pathogenic potential of Pantoea agglomerans strains isolated from mango trees. In both pathogenicity experiments, onion bulbs and apical buds from mango trees were selected and bacterial isolation and identification using biochemical and physiological tests was performed, which fulfilled Koch's postulates.

Ten Pantoea agglomerans strains were selected to perform the pathogenicity assay on onion bulbs. The selected P. agglomerans strains (with the exception of the strain UMAF3090) produced bulb rot symptoms in onion bulbs (Fig. 2) at 28 days postinoculation. P. stewartii subsp. indologenes CFBP3614 was included as positive control. No symptoms were detected in onion bulbs inoculated with the negative controls (phosphate buffer and two nonpathogenic strains of $P$. agglomerans, CECT850 and CFBP4740).

To fulfill Koch's postulates on mango trees, a pathogenicity test on 2-year-old mango plants was carried out with five selected $P$. agglomerans strains that were isolated from mango trees. Similar to the Pseudomonas syringae pv. syringae control strains used in this experiment, all of the inoculated strains induced necrotic symptoms in mango buds, and some did so on stems (Fig. 1F and G). $P$. syringae pv. syringae control strains produced visible necrotic symptoms just 1 month after the inoculation, reaching disease incidence values of $42.8 \%$. Two months after inoculation, $P$. syringae pv. syringae showed the highest disease incidence values $(92.8 \%)$. Similarly, the first necrotic symptoms induced by Pantoea agglomerans strains appeared 2 months after the inoculation, reaching disease incidence values of $17.1 \%$, indicating that there was a delay in the onset of necrotic symptoms with respect
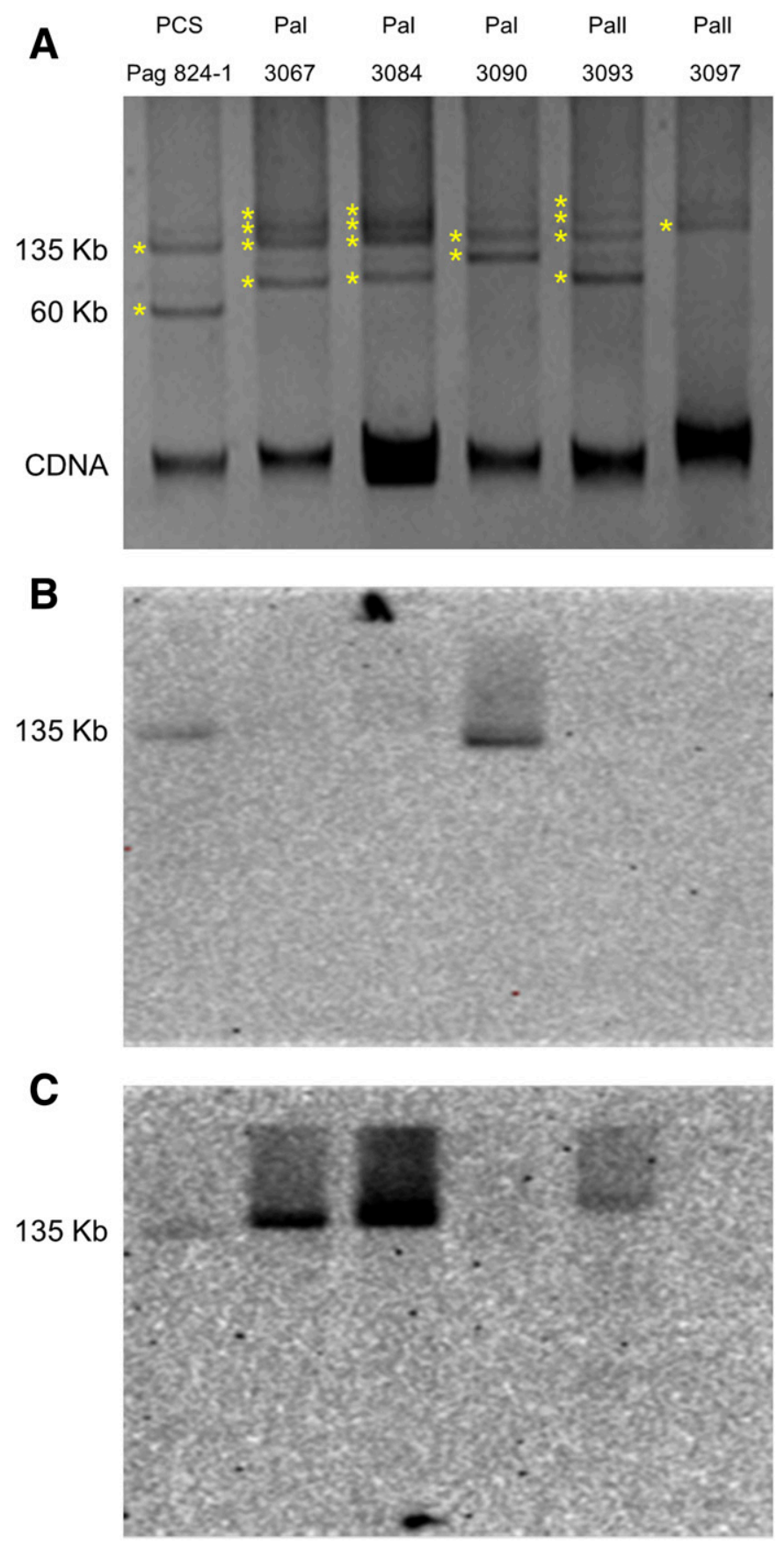

Fig. 3. Plasmid profile and detection of repA and hrpJ genes by Southern blot hybridization. A, Plasmid profile of some Pantoea agglomerans strains isolated from mango that are representative of the diversity of plasmids found in the $P$. agglomerans population. P. agglomerans pv. gypsophilae control strain (Pag 824-1) that harbors two plasmids: a $60-\mathrm{kb}$ plasmid and a plasmid belonging to the pPATH family of $135 \mathrm{~kb}$. UMAF3067 and UMAF3084 harbor four plasmids: approximately 90, 140, 150, and $160 \mathrm{~kb}$. UMAF3090 harbors two plasmids: approximately 110 and $140 \mathrm{~kb}$. UMAF3093 harbors four plasmids: approximately 90, 140, 160, and $170 \mathrm{~kb}$. UMAF3097 harbors one plasmid: approximately $150 \mathrm{~kb}$. $\mathrm{PCS}=$ pathogenic control strain, $\mathrm{PaI}=$ phylogroup PaI, PaII = phylogroup PaII, and CDNA = chromosomal DNA. B, Southern blot hybridization of repA gene at high stringency, $55^{\circ} \mathrm{C}$. C, Southern blot hybridization of $h r p J$ gene at low stringency, $45^{\circ} \mathrm{C}$. 
to the Pseudomonas syringae pv. syringae strains. A $100 \%$ disease incidence was reached at 3.5 months after the inoculation with Pantoea agglomerans. Apical buds inoculated with P. agglomerans CFBP4740 and phosphate buffer did not show any necrotic symptoms (Table 2).
Plasmids of $P$. agglomerans strains from mango trees do not belong to the pPATH family. $P$. agglomerans was previously described as having evolved to be a pathogen by the acquisition of pathogenicity plasmids from the pPATH family (Manulis and Barash 2003). Thus, the presence of plasmids was analyzed in the
A

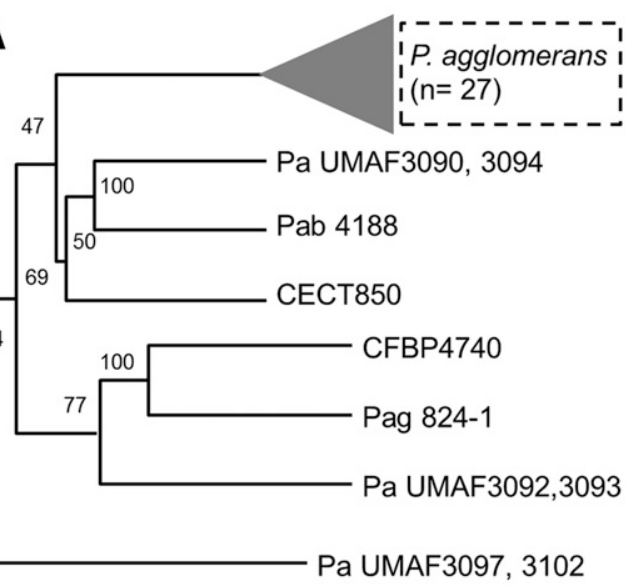

B

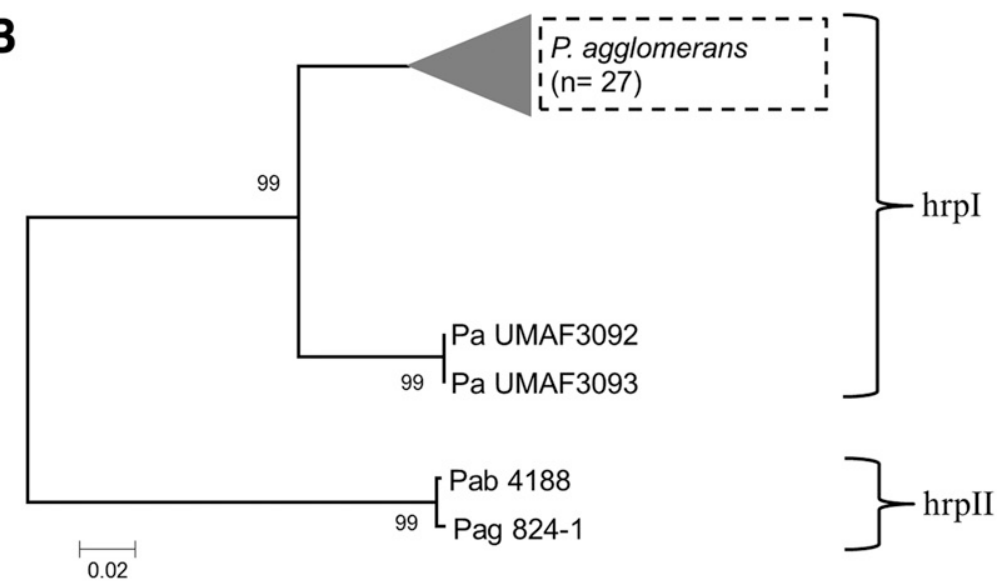

C

100

P. agglomerans Mango phylogroup ' i $(n=27)$

100

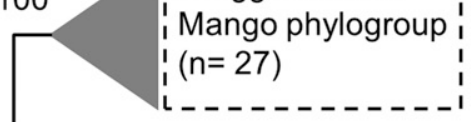
$\square \square \square$

Pa UMAF3090
Pa UMAF3094

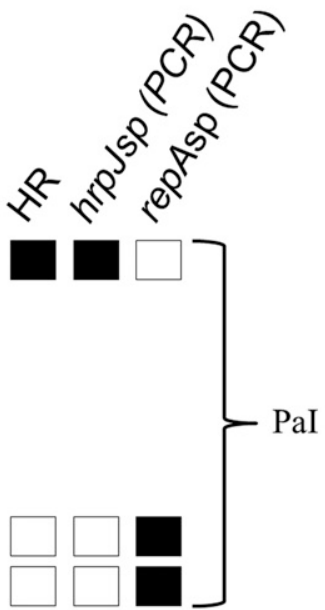

$\mathrm{PaI}$

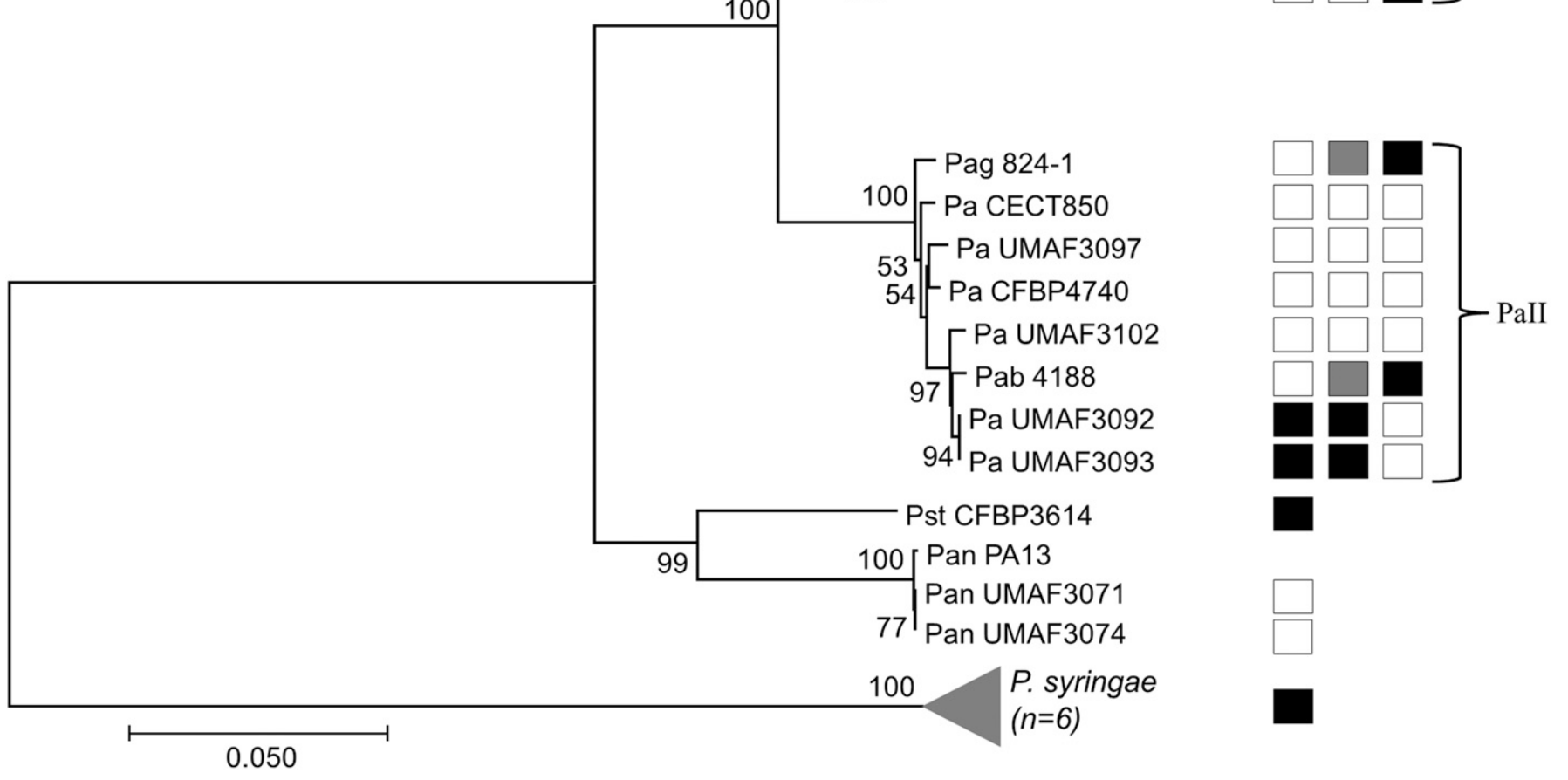


$P$. agglomerans strains isolated from mango trees. Four plasmids were identified in 27 of 29 putatively pathogenic $(n=23)$ and pathogenic $(n=4)$ P. agglomerans strains (with approximate sizes of $90,140,150$, and $160 \mathrm{~kb}$ ), one of which was close in size to the pPATH pathogenicity plasmid $(135 \mathrm{~kb})$ of the control strain $824-1$ used in this study. The other two strains, putatively pathogenic UMAF3092 and pathogenic UMAF3093, harbored four plasmids but with some differences in sizes (approximately 90, 140, 160, and $170 \mathrm{~kb}$ ). The four putatively nonpathogenic $P$. agglomerans strains isolated from mango trees harbored two different plasmid profiles; UMAF3090 and UMAF3094 contain two plasmids (approximately 110 and $140 \mathrm{~kb}$ ) and UMAF3097 and UMAF3102 carry only one plasmid (approximately $150 \mathrm{~kb}$ ) (Fig. 3A).

PCR using specific primers to amplify repA were designed in this study onto the sequences of repA from strains 824-1 and 4188, as mentioned above. Amplicon electrophoresis revealed that the replication gene repA was only present in the putatively nonpathogenic mango strains UMAF3090 and UMAF3094, and the amplicon sequencing showed a high level of nucleotide identity (over than $96 \%$ in comparison with repA from strains 824-1 and 4188). Finally, Southern blot experiments using plasmid profiles gels of selected strains confirmed that the repA gene was only detected in UMAF3090 in the 140-kb plasmid (Fig. 3B).

Because pPATH plasmids have been described as harboring an important PAI that encodes the T3SS (Manulis and Barash 2003), among other genes, P. agglomerans strains isolated from mango trees were analyzed to investigate the presence of the $h r p J$ gene. The PCR analysis showed that all putatively and confirmed pathogenic $P$. agglomerans strains from mango trees $(n=29)$ tested were positive for the presence of an amplicon of the expected size, and the result with confirmed pathogenic strains correlates with their positive HR response on tobacco leaves. In contrast, the four putatively nonpathogenic $P$. agglomerans strains tested were negative. This PCR experiment was carried out using the primers designed by Weinthal et al. (2007). Because amplification of nonspecific bands was observed, an amplicon of the expected size was difficult to recover from agarose gels for all of the assayed strains. Some of the amplicons were recovered, purified, cloned, transformed in E. coli DH5 $\alpha$, and sequenced. By using the specific primers designed in this study, which were based on previously obtained sequences, we obtained partial hrpJ gene-specific sequences for the 29 putative pathogenic and pathogenic strains of $P$. agglomerans. Again, the PCR amplification was negative for the four putatively nonpathogenic strains of $P$. agglomerans. Almost all $P$. agglomerans strains from mango trees yielded a positive PCR result for the presence of the hrpJ gene, showing a high degree of identity for the partial $h r p J$ gene sequence, except for UMAF3092 and UMAF3093, which showed small differences but were identical to one another ( $91.4 \%$ of identity). In addition, a greater difference was observed regarding the nucleotide identity of the partial $h p r J$ sequence from the 27 putatively pathogenic and pathogenic $P$. agglomerans strains from mango trees compared with the pathogenic strains $824-1$ and 4188 ( $77.1 \%$ of identity). Because the Southern blot analysis at $55^{\circ} \mathrm{C}$ only detected the presence of the hrpJ gene in the two selected pathogenic P. agglomerans strains isolated from mango trees (UMAF3067 and UMAF3084), we could not confirm in which of the four plasmids this gene was present. Southern blot experiments at $45^{\circ} \mathrm{C}$ confirmed the presence of the hrpJ gene in the 135-kb pPATH plasmid of the control strain 824-1, revealing the presence of this gene in the $140-\mathrm{kb}$ plasmid in two selected pathogenic strains of $P$. agglomerans isolated from mango trees (UMAF3067 and UMAF3084). In pathogenic UMAF3093, this gene was detected in the 160-kb plasmid (Fig. 3C).

Genetic and phylogenetic analyses revealed a differentiated phylogroup of $P$. agglomerans strains isolated from mango trees. By using a DNA fingerprinting rep-PCR method with the BOXA1R primer, we observed that the generated dendrogram displayed a primary cluster with 27 of the putatively pathogenic and pathogenic $P$. agglomerans strains isolated from mango trees. The remaining putatively pathogenic UMAF3092, pathogenic UMAF3093, and putatively nonpathogenic (UMAF3090, UMAF3094, UMAF3097, and UMAF3102) $P$. agglomerans strains isolated from mango trees were distributed randomly along with the pathogenic and nonpathogenic $P$. agglomerans control strains (Fig. 4A).

Next, a phylogenetic analysis based on the hrpJ gene sequences was carried out, taking into account that the UMAF3090, UMAF3094, UMAF3097, UMAF3102, and $P$. agglomerans nonpathogenic controls strains could not be utilized because they were negative for the presence of this gene by PCR. Two main phylogroups were generated, hrpI and hrpII (Fig. 4B). It is noteworthy that, inside the hrpI phylogroup, two subphylogroups arose, one that was composed of almost all P. agglomerans strains isolated from mango trees (the same 27 strains that clustered together using rep-PCR) and a second that was composed of the remaining putatively pathogenic and pathogenic strains, UMAF3092 and UMAF3093, respectively. Both subphylogroups contained different variants of the hrpJ gene. The hrpII phylogroup was composed of strains 824-1 and 4188, the control pathogenic strains included in this study.

After performing the genetic diversity and phylogenetic distribution analyses based on the hrpJ gene sequences, a phylogenetic analysis based on the $g y r B$ and $r p o B$ housekeeping gene sequences was performed that included all of the bacterial strains isolated from mango trees and all Pantoea control strains used in this work (Fig. 4C). The phylogenetic distribution generated two primary phylogroups, PaI and PaII. The PaI phylogroup was composed of 27 of the 29 putatively pathogenic and pathogenic (only 5 confirmed in mango) $P$. agglomerans strains from mango trees that were positive for the HR response and for the presence of the $h r p J$ gene. In addition, two putatively nonpathogenic P. agglomerans strains (UMAF3090 and UMAF3094), both positive for the presence of repA gene but negative for the HR response and the presence of $h r p J$ gene, were included in this phylogroup but in a separate branch. A second phylogroup (PaII) was primarily composed of pathogenic (824-1, 4188, and UMAF3093), putatively pathogenic (UMAF3092), and

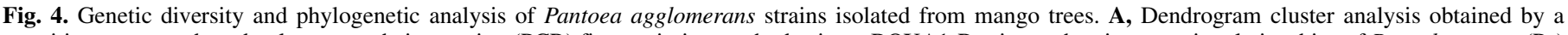

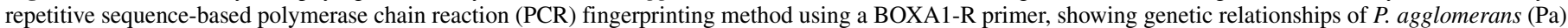

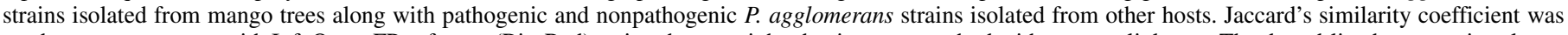

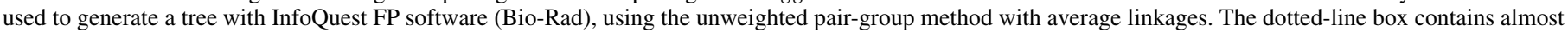

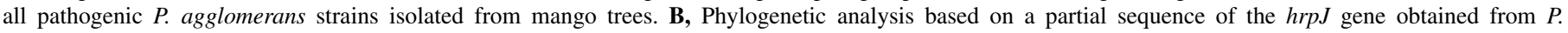

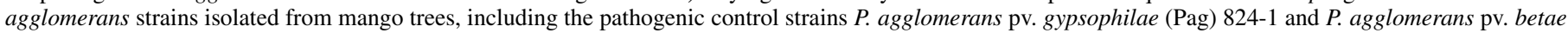

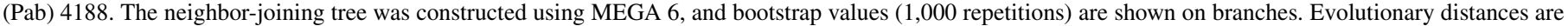

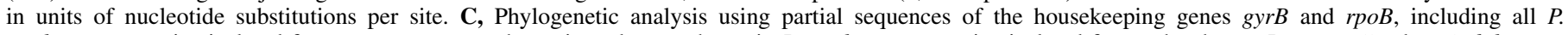

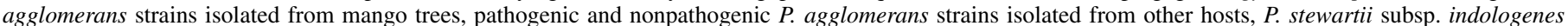

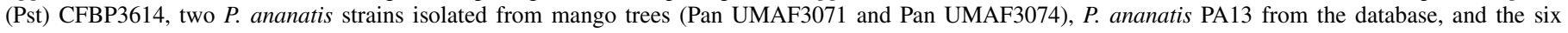

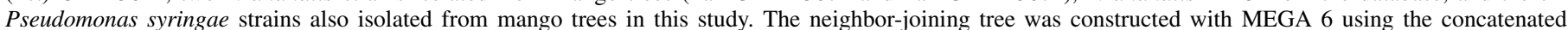

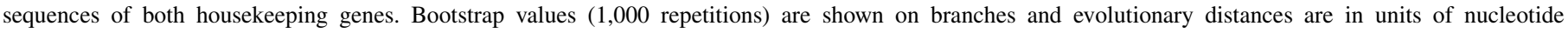

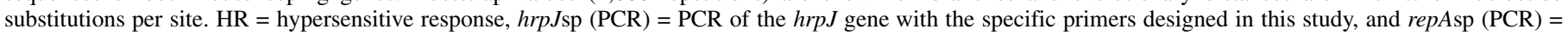

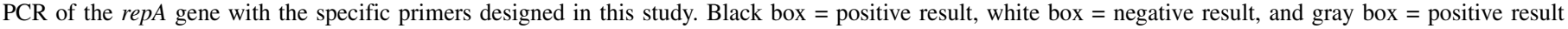

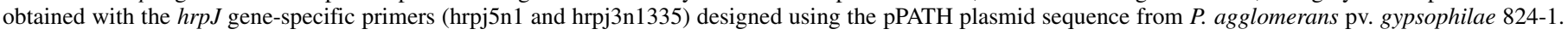


nonpathogenic and putatively nonpathogenic (CECT850, CFPB 4740, UMAF3097, and UMAF3102) P. agglomerans strains isolated from mango trees and other hosts.

\section{DISCUSSION}

In this study, a new etiological agent of a bacterial necrotic disease has been described in mango crops in the Canary Islands. Pseudomonas syringae pv. syringae is the described causal agent of BAN disease of mango trees worldwide (Cazorla et al. 1998), which is the major limiting factor for the productivity of mango crop yields in the Mediterranean region (Cazorla et al. 1998, 2006; GutiérrezBarranquero et al. 2012). The necrotic symptoms produced by this new etiological agent are similar to those produced by $P$. syringae pv. syringae, with the main difference being that this bacterium can also affect immature fruit and flower panicles (Fig. 1). The nonfluorescent and yellow colonies isolated from diseased mango tissues from different years and orchards in the Canary Islands were consistently identified as Pantoea agglomerans on the basis of their physiological and biochemical profiles (Table 1) (Gavini et al. 1989).

Nucleotide sequence analysis of the $16 \mathrm{~S}$ ribosomal RNA gene has been used to reveal taxonomic discrepancies in the Pantoea genus (Rezzonico et al. 2009) but the use of housekeeping genes has shown a better resolution to classify and identify different Pantoea spp. (Delétoile et al. 2009). In this study, the use of nucleotide sequences of the housekeeping genes $g y r B$ and $r p o B$ conclusively confirmed that the bacterial isolates from mango trees belonged to $P$. agglomerans species. Of the $33 P$. agglomerans mango tree isolates, 29 were positive for the HR response, suggesting their potential as pathogenic bacteria, as was previously reported in P. agglomerans pv. gypsophilae (Nizan et al. 1997). Although $P$. agglomerans is a frequent epiphytic and endophytic bacterium (Walterson and Starvinides 2015), it has been reported to cause diseases in different plant hosts (Lu et al. 2015; Tho et. al 2015). In particular, it has been demonstrated that $P$. agglomerans has evolved to be a plant pathogen through the acquisition of pathogenicity plasmids of the so-called pPATH family (Manulis and Barash 2003). Plasmids in this family share the major replication protein RepA (Weinthal et al. 2007) with a high identity (over $98 \%$ ) and are characterized by the presence of a PAI that includes genes involved in the production of phytohormones, the T3SS, and different pools of T3 effectors (Barash and ManulisSasson 2007, 2009; Manulis and Barash 2003). Interestingly, this bacterium has been previously reported as a possible mango pathogen in China, where it was observed to only produce necrotic lesions on leaves; however, the pathogenicity mechanisms remain to be elucidated (Lee and Tzeng 2006).

After the bacterial isolates in this study were identified as $P$. agglomerans, their role in the induction of necrotic symptoms in mango trees was analyzed. P. agglomerans has been previously described to cause bulb rot in onion in Georgia and Michigan (Edens et al. 2006; Tho et al. 2015). Thus, this pathosystem can serve as an initial and simpler approach to unravel the pathogenicity of $P$. agglomerans strains isolated from mango trees. All assayed P. agglomerans isolates from mango trees $(n=10$, with the exception of UMAF3090) exhibited bulb rot symptoms, confirming that these isolates are pathogenic against onion (Fig. 2A). Subsequently, a pathogenicity assay in mango plants confirmed the role of a number of selected $P$. agglomerans strains in the induction of necrotic symptoms in mango buds similar to those produced by BAN (Fig. $2 \mathrm{~B}$ ). These results support $P$. agglomerans as a new etiological agent of a bacterial necrotic disease of mango trees in the Canary Islands. It was previously described that Pseudomonas syringae pv. syringae populations and disease severity are higher during cool and wet seasons (autumn and winter) and are lower in warm seasons in southern Spain (Cazorla et al. 1998). These data could support the delay and the development of necrotic symptoms produced by Pantoea agglomerans with respect to Pseudomonas syringae pv. syringae during the pathogenicity test in mango trees, because it was performed in Malaga (mainland Spain). Moreover, this could explain the presence of Pantoea agglomerans rather than Pseudomonas syringae pv. syringae in the Canary Islands but not in southern Spain due to the milder environmental conditions. In particular, mango trees reach a dormancy period when the temperature is below $15^{\circ} \mathrm{C}$ (Samson 1986), which correlates with the minimum temperature in winter in southern Spain (specifically in Malaga), giving rise to the most destructive BAN symptoms. In the Canary Islands, the minimum temperature is rarely lower than $15^{\circ} \mathrm{C}$. Thus, the development of BAN symptoms is unusual in the Canary Islands, and this could promote the emergence of alternative pathogens such as Pantoea agglomerans.

To shed light on the possible mechanisms involved in the pathogenicity of $P$. agglomerans strains isolated from mango trees, the presence of plasmids and the detection of relevant genes present on pPATH family plasmids were evaluated (Fig. 3). Some $P$. agglomerans strains isolated from mango trees that exhibited a positive HR response in tobacco leaves caused bulb rot in onion $(n=10)$ and produce necrotic symptoms in mango buds $(n=4)$ harbored the same plasmid profile, consisting of four different plasmids. The T3SS system present in pPATH plasmids is one of the major virulence factors of $P$. agglomerans (Nizan-Koren et al. 2003). By a PCR approach, those putatively pathogenic and pathogenic strains of $P$. agglomerans were all positive for the presence of the of the T3SS hrpJ gene. Interestingly, the pathogenic P. agglomerans strains from mango UMAF3067 and UMAF3084 were positive for the presence of the T3SS hrpJ gene in the 140-kb plasmid. However, these strains were negative for the presence of a unique gene shared by all pPATH plasmids, the replication gene repA. Thus, our results suggest that the $140-\mathrm{kb}$ plasmid harbored by the pathogenic $P$. agglomerans strains isolated in this study was different than that belonging to the previously described pPATH pathogenicity plasmids, and the presence of the T3SS hrpJ gene could suggest a role for this plasmid in their pathogenicity. The presence of the pPATH repA gene was only demonstrated in the 140kb plasmid of two strains (UMAF3090 and UMAF3094), which were negative for the HR response and negative for the presence of hrpJ gene; and UMAF3090, specifically, failed to elicit bulb rot in onion, resulting in these strains being considered putatively nonpathogenic. Despite the presence of the repA gene in these two bacterial strains, in pPATH plasmids, the T3SS is located in a pathogenicity island (Barash and Manulis-Sasson 2007) which could be complete or partially lost during their evolutionary history.

Subsequently, a genetic diversity analysis of $P$. agglomerans strains isolated from mango trees was performed using rep-PCR. Three different groups were generated that were composed of different $P$. agglomerans strains isolated from mango trees and other hosts. It is important to highlight the fact that rep-PCR provided an important subgroup differentiation, because 27 of the 29 putatively pathogenic and pathogenic $P$. agglomerans strains that share the same $h r p J$ gene variant clustered together (Fig. 4A). The band pattern obtained for these strains was identical, suggesting a clonal origin of this population associated potentially with the induction of necrotic symptoms in mango plants on the Canary Islands. rep-PCR was successfully used to differentiate the melon-infecting P. ananatis from other Pantoea spp., including P. agglomerans (Kido et al. 2008), and was recently used to reveal limited genetic diversity among $P$. ananatis strains causing bulb rot in onion (Stice et al. 2018). To determine whether the observed genetic clustering is consistent with the evolutionary history of putatively pathogenic and pathogenic $P$. agglomerans strains isolated from mango trees, a phylogenetic analysis was performed using the housekeeping gyrB and $r p o B$ genes (Fig. 4C). Despite a previous report describing that the phylogenetic distribution of $P$. agglomerans was indistinguishable between clinical and environmental P. agglomerans isolates (Brady et al. 2008; Delétoile et al. 2009; Rezzonico et al. 2009), in this study, a primary phylogroup comprising 27 of the 29 putatively 
pathogenic and pathogenic $P$ agglomerans strains was observed. This result showed a similar tendency to that observed previously in a genetic diversity analysis, suggesting a specific and different evolutionary history of these isolates than pathogenic and nonpathogenic $P$. agglomerans strains isolated from different hosts, which could be determined by the adaption of this group to the mango host and the environmental conditions of this crop in the Canary Islands. In addition, a phylogenetic analysis based on the hrpJ gene sequences generated a main mango phylogroup that again included a subcluster containing 27 of the 29 putatively pathogenic and pathogenic $P$. agglomerans isolates. It is important to note that the hrpJ gene sequences were practically identical for each subcluster and were different between them, as was highlighted above. These results again show an identical tendency obtained previously with genetic and phylogenetic analyses. Interestingly, this may suggest that plasmids harbored by P. agglomerans strains isolated from mango trees came from a common ancestor and, after this acquisition event, they followed the same evolutionary history as their bacterial hosts, likely influenced by other factors during their adaptation to the mango host. In addition, it is of interest to note that the two remaining $P$. agglomerans strains isolated from mango (putatively pathogenic UMAF3092 and pathogenic UMAF3093) were different from the main 27 P. agglomerans strains at different levels, being more phylogenetically related to the original $P$. agglomerans cluster PaII.

Overall, these data support the idea that $P$. agglomerans is a new etiological agent that causes a bacterial necrotic disease associated with the mango tree host in the Canary Islands. Impressively, different levels of genetic characterization and phylogenetic distribution analyses revealed that these strains mostly form a differentiated and clonal phylogroup with respect to other pathogenic P. agglomerans strains that were previously described from other hosts

\section{ACKNOWLEDGMENTS}

We thank S. Manulis-Sasson and I. Barash for kindly providing the pathogenic strains $P$. agglomerans pv. gypsophilae 824-1 and P. agglomerans pv. betae 4188, and D. Fernández Galván and E. García for their help in sampling.

\section{LITERATURE CITED}

Aiello, D., Ferrante, P., Vitale, A., Polizzi, G., Scortichini, M., and Cirvilleri, G. 2015. Characterization of Pseudomonas syringae pv. syringae isolated from mango in Sicily and occurrence of copper-resistant strains. J. Plant Pathol. 97:273-282.

Barash, I., and Manulis-Sasson, S. 2007. Virulence mechanisms and host specificity of gall forming Pantoea agglomerans. Trends Microbiol. 15: 538-545.

Barash, I., and Manulis-Sasson, S. 2009. Recent evolution of bacterial pathogens: The gall forming Pantoea agglomerans case. Annu. Rev. Phytopathol. 47:133-152.

Bradbury, J. F. 1986. Guide to Plant Pathogenic Bacteria. CAB International, Farnham Royal, Slough, UK.

Brady, C., Cleenwerck, I., Venter, S., Vancanneyt, M., Swings, J., and Coutinho, T. 2008. Phylogeny and identification of Pantoea species associated with plants, humans and the natural environment based on multilocus sequence analysis (MLSA). Syst. Appl. Microbiol. 31:447-460.

Burr, T. J., Katz, B. H., Abawi, G. S., and Crosier, D. C. 1991. Comparison of tumorigenic strains of Erwinia herbicola isolated from table beet with $E$. $h$. gypsophilae. Plant Dis. 75:855-858.

Büyükcam, A., Tuncer, Ö., Gür, D., Sancak, B., Ceyhan, M., Cengiz, A. B., and Kara, A. 2018. Clinical and microbiological characteristics of Pantoea agglomerans infection in children. J. Infect. Public Health 11: 304-309.

Cazorla, F. M., Arrebola, E., Olea, F., Velasco, L., Hermoso, J. M., Pérez-García, A., Torés, J. A., Farré, J. M., and de Vicente, A. 2006. Field evaluation of treatments for the control of the bacterial apical necrosis of mango (Mangifera indica) caused by Pseudomonas syringae pv. syringae. Eur. J. Plant Pathol. 116:279-288.

Cazorla, F. M., Torés, J. A., Olalla, L., Pérez-García, A., Farré, J. M., and de Vicente, A. 1998. Bacterial apical necrosis of mango in Southern Spain:
A disease caused by Pseudomonas syringae pv. syringae. Phytopathology 88:614-620.

Cheng, A., Liu, C. Y., Tsai, H. Y., Hsu, M. S., Yang, C. J., Huang, Y. T., Liao, C. H., and Hsueh, P. R. 2013. Bacteremia caused by Pantoea agglomerans at a medical center in Taiwan, 2000-2010. J. Microbiol. Immunol. Infect. 46:187-194.

Cooksey, D. A. 1986. Galls of Gypsophila paniculata caused by Erwinia herbicola. Plant Dis. 70:464-468.

Cruz, A. T., Cazacu, A. C., and Allen, C. H. 2007. Pantoea agglomerans, a plant pathogen causing human disease. J. Clin. Microbiol. 45:1989-1992.

DeYoung, R. M., Copeman, R. J., and Hunt, R. S. 1998. Two strains in the genus Erwinia cause galls on Douglas fir in Southern British Columbia. Can. J. Plant Pathol. 20:194-200.

Delétoile, A., Decré, D., Courant, S., Passet, V., Audo, J., Grimont, P., Arlet, G., and Brisse, S. 2009. Phylogeny and identification of Pantoea species and typing of Pantoea agglomerans strains by multilocus gene sequencing. J. Clin. Microbiol. 47:300-310.

Edens, D. G., Gitaitis, R. D., Sanders, F. H., and Nischwitz, C. 2006. First report of Pantoea agglomerans causing a leaf blight and bulb rot of onions in Georgia. Plant Dis. 90:1551.

Gagnevin, L., and Pruvost, O. 2001. Epidemiology and control of mango bacterial black spot. Plant Dis. 85:928-935.

Galán Saúco, V. 2015. Current situation and future prospects of worldwide mango production and market. Acta Hortic. 1066:69-84.

Gavini, F., Mergaert, J., Beji, A., Mielcarek, C., Izard, D., Kersters, K., and De Ley, J. 1989. Transfer of Enterobacter agglomerans (Beijerinck 1888) Ewing \& Fife 1972 to Pantoea gen. nov. as Pantoea agglomerans comb. nov. and description of Pantoea dispersa sp. nov. Int. J. Syst. Bacteriol. 39: $337-345$

Golzar, H., and Cother, E. 2008. First report of bacterial necrosis of mango caused by Pseudomonas syringae pv. syringae in Australia. Australas. Plant Dis. Notes 3:107-109.

González, A. D., Franco, M. A., Contreras, N., Galindo-Castro, I., Jayaro, Y., and Graterol, E. 2015. First report of Pantoea agglomerans causing rice leaf blight in Venezuela. Plant Dis. 99:552.

Guevara, Y., Rondón, A., and Solórzano, R. 1980. Bacteriosis del mango (Mangifera indica L.) en Venezuela. I. Sintomatología e identificación. Agron. Trop. 30:65-76.

Gutiérrez-Barranquero, J. A., Arrebola, E., Bonilla, N., Sarmiento, D., Cazorla, F. M., and de Vicente, A. 2012. Environmentally friendly treatment alternatives to Bordeaux mixture for controlling bacterial apical necrosis (BAN) of mango. Plant Pathol. 61:665-676.

Jacobs, J. L., Fasi, A. C., Ramette, A., Smith, J. J., Hammerschmidt, R., and Sundin, G. W. 2008. Identification and onion pathogenicity of Burkholderia cepacia complex isolates from the onion rhizosphere and onion field soil. Appl. Environ. Microbiol. 74:3121-3129.

Kido, K., Adachi, R., Hasegawa, M., Yano, K., Hikichi, Y., Takeuchi, S., Atsuchi, T., and Takikawa, Y. 2008. Internal fruit rot of netted melon caused by Pantoea ananatis (=Erwinia ananas) in Japan. J. Gen. Plant Pathol. 74: 302-312.

Kim, Y., Lee, S., Choi, C., Lee, S., and Lee, S. 2002. Soft rot of onion bulbs caused by Pseudomonas marginalis under low temperature storage. Plant Pathol. J. 18:199-203.

King, E. O., Ward, M. K., and Raney, D. E. 1954. Two simple media for the demonstration of pyocyanin and fluorescin. J. Lab. Clin. Med. 44:301-307.

Lee, H. B., Hong, J. P., and Kim, S. B. 2010. First report of leaf blight caused by Pantoea agglomerans on rice in Korea. Plant Dis. 94:1372.

Lee, M. H., and Tzeng, D. D. S. 2006. Pantoea agglomerans MB-9 is a potential pathogen causing necrosis on mango leaf. Plant Pathol. Bull. 15: 63-68.

Lelliott, R. A., and Stead, D. E. 1987. Methods for the diagnosis of bacterial diseases of plants. Pages 44-56 in: Methods in Plant Pathology, Vol. 2. T. F. Preece, ed. Blackwell Scientific Publications, Oxford, UK.

Lindgren, P. B. 1997. The role of $h r p$ genes during plant-bacterial interactions. Annu. Rev. Phytopathol. 35:129-152.

Lu, B. H., Jia, M. J., and Gao, J. 2015. First report of Pantoea agglomerans causing Bacterial leaf blight on Vigna angularis in Jilin Province, China. Plant Dis. 99:1269.

Manulis, M., and Barash, I. 2003. Pantoea agglomerans pvs. gypsophilae and betae, recently evolved pathogens? Mol. Plant Pathol. 4:307-314.

Manulis, M., Gafni, Y., Clark, E., Zutra, D., Ophir, Y., and Barash, I. 1991. Identification of a plasmid DNA probe for detection of strains of Erwinia herbicola pathogenic on Gypsophila paniculata. Phytopathology 81:54-57.

McMillan, R. T., and Wang, A. 1992. A new disease of mango in Costa Rica caused by Erwinia-like bacteria. Proc. Fla. State Hortic. Soc. 105:288-289.

Moulton, J. L., Vivian, A., Hunter, P. J., and Taylor, J. D. 1993. Changes in cultivar-specificity toward pea can result from transfer of plasmid RP4 and other incompatibility group P1 replicons to Pseudomonas syringae pv. pisi. J. Gen. Microbiol. 139:3149-3155. 
Naqvi, S. A. H., Perveen, R., Rehman, A. U., Khan, T., Malik, M. T., Chohan, S., Tariq, A., and Abbas Pak, S. H. 2016. Outbreak of bacterial apical necrosis of mango in Multan, Punjab, Pakistan. Pak. J. Phytopathol. 28: 107-113.

Nizan, R., Barash, I., Valinsky, L., Litcher, A., and Manulis, S. 1997. The presence of $h r p$ genes on the pathogenicity associated plasmid of the tumorigenic bacterium Erwinia herbicola pv. gypsophilae. Mol. PlantMicrobe Interact. 5:667-682.

Nizan-Koren, R., Manulis, S., Mor, H., Iraki, N., and Barash, I. 2003. The regulatory cascade that activates the Hrp regulon in Erwinia herbicola pv. gypsophilae. Mol. Plant-Microbe Interact. 15:1249-1260.

Opgenorth, D. C., Hendson, T. M., and Clark, E. 1994. First report of a bacterial gall of a Wisteria sinensis caused by Erwinia herbicola pv. milletiae in California. Plant Dis. 78:1217.

Pinkas, Y., Maymon, M., and Smolewich, Y. 1996. Bacterial black blight of mango. Alon Hanotea 50:475.

Rademaker, J. L. W., Louws, F. J., Versalovic, J., and de Bruijn, F. J. 2004. Characterization of the diversity of ecologically important microbes by repPCR genomic fingerprinting. Pages 1-33 in: Molecular Microbial Ecology Manual, second ed. G. A. Kowalchuk, F. J. de Bruijn, I. M. Head, A. D. Akkermans, and J. D. van Elsas, eds. Kluwer Academic Publishers, Dordrecht, The Netherlands.

Rezzonico, F., Smits, T. H., Montesinos, E., Frey, J. E., and Duffy, B. 2009. Genotypic comparison of Pantoea agglomerans plant and clinical strains. BMC Microbiol. 9:204.
Samson, J. A. 1986. Tropical Fruits, 2nd ed. Logman Scientific \& Technical, Essex, NY.

Stice, S. P., Stumpf, S. D., Gitaitis, R. D., Kvitko, B. H., and Dutta, B. 2018. Pantoea ananatis genetic diversity analysis reveals limited genomic diversity as well as accessory genes correlated with onion pathogenicity. Front. Microbiol. 9:184.

Tamura, K., Stecher, G., Peterson, D., Filipski, A., and Kumar, S. 2013. MEGA6: Molecular evolutionary genetics analysis version 6.0. Mol. Biol. Evol. 30:2725-2729.

Tho, K. E., Wiriyajitsomboon, P., and Hausbeck, M. K. 2015. First report of Pantoea agglomerans causing onion leaf blight and bulb rot in Michigan. Plant Dis. 99:1034.

Trantas, E. A., Mpalantinaki, E., Pagoulatou, M., Markakis, E., Sarris, P. F., Ververidis, F., and Goumas, D. E. 2017. First report of bacterial apical necrosis of mango caused by Pseudomonas syringae pv. syringae in Greece. Plant Dis. 101:1541.

Walterson, A. M., and Starvinides, J. 2015. Pantoea: Insights into a highly versatile and diverse genus within the Enterobacteriaceae. FEMS Microbiol. Rev. 39:968-984.

Weinthal, D. M., Barash, I., Panijel, M., Valinsky, L., Gaba, V., and Manulis-Sasson, S. 2007. Distribution and replication of the pathogenicity plasmid pPATH in diverse populations of the gall-forming bacterium Pantoea agglomerans. Appl. Environ. Microbiol. 73:7552-7561.

Yang, Q. K., Qu, W. W., Liu, X., Liu, H. X., and Hou, L. Q. 2011. First report of Pantoea agglomerans causing brown apical necrosis of Walnut in China. Plant Dis. 95:773. 